\title{
Exploring the Adjustment Problems among International Graduate Students in Hawaii
}

\author{
Stephanie Yang ${ }^{1, *}$, Michael Salzman ${ }^{1}$, Cheng-Hong Yang ${ }^{2}$ \\ ${ }^{1}$ University of Hawaii, USA \\ ${ }^{3}$ National Kaohsiung University of Applied Sciences, Taiwan
}

Copyright $@ 2015$ Horizon Research Publishing All rights reserved.

\begin{abstract}
Due to the advance of technology, the American society has become more diverse. A huge population of international students in the U.S. faces unique issues. According to the existing literature, the top-rated anxieties international student faces are generally caused by language anxiety, cultural adjustments, and learning differences and barriers. In the university campus that is being studied in Hawaii, the highest population of students is Asian. As a matter of fact, Hawaii is the only state in USA that does not have a majority of white population. This research study examined anxiety levels as international graduate students living in Hawaii, U.S. This study emphasizes on the wide variety of factors and whether it has an influence on the predicators of anxiety. Learning difficulties and life challenges for international graduate students in Hawaii were also examined. "Communication ability", "interactions with professors", "limited course options", and "course content difficulty" were the most experienced learning difficulties. "Financial crisis", "quality of accommodation", "relationship with people", and "language" were the most experienced life challenges. Understanding the experiences of the international graduate students is important on creating supporting programs to help them personally and academically to fit in the environment.
\end{abstract}

Keywords Anxiety, International, Graduate, Student

\section{Introduction}

The issue

Pursuing a higher-education degree provides the student an opportunity to broaden their knowledge of other cultures and the ability to speak the language. The experience of studying abroad also enhances the students' competitiveness in the global labor industry. It is inevitable to say that studying abroad is a desirable experience for most students. Regardless of the educational and social strengths, studying abroad also brings economic impacts to the host countries. Enrolling international students not only raise revenues, but also present a broader strategy on recruiting well-trained and highly skilled immigrants [1]. In 2013, almost 4.3 million students were enrolled in academic institutions outside of their home country [1]. The Organization for Economic Co-operation and Development (OECD) noted that Australia, Germany, France, Canada, the United Kingdom and the United States receive more than $50 \%$ of all foreign-student population worldwide.

\section{Purpose of study}

The purpose of this study is to document the empirical predictors of anxieties that international graduate students experience throughout their learning period in Hawaii, which hopes to fill in the literature gap. Currently, there are no studies shown that investigate in the experience of international graduate student living in Hawaii. According to Open Doors Report [2], there are nearly 4,500 foreign students in Hawaii. The top three leading places of the origins of the foreign students are Japan, South Korea, and China. In addition, as the only Asian plurality state, the research based on the university campus in Hawaii will discover different college experiences and anxieties for the international graduate students. With the wide range of culture and ethnic groups within the population, Hawaii is a very unique environment that is believed to have a great difference when compared to other states. It is to believe that the present study will distinct widely from the previous existing literatures that are conducted in other states.

\section{Research questions}

This study is specifically interested in the following research question.

1. What are the most common challenges of studying and living in Hawaii that are most encountered by international graduate students?

\section{Literature Review}

What is anxiety?

According to Kim [3], anxiety is the subjective and physiological concomitants of anticipation of future danger 
or fear of consequences of current behavior. There are various evidences to show the relationship between biological factors and psychological issues. For example, Bremmer [4] reported that the hippocampus, which has the capacity to regenerate neurons and involves with memory and emotion in the brain, can be damaged by extreme stressors such as child abuse. This creates the lasting effect of psychological trauma that may produce anxiety. Feldman [5] also pointed out that there are some personality characteristics that have genetic factors and a specific gene that has great influences in determining risk-taking behavior. Anxiety can be categorized into various forms. From Alpert and Haber's [6] study, there are two types of anxieties that will make big difference to individual's learning, which are facilitating and debilitating anxiety. They pointed out that facilitating anxiety is motivational and beneficial, which will help promote better performance. On the other hand, debilitating anxiety has a negative effect on students, which will likely cause detrimental influences on the performance.

\section{Language anxiety}

Language anxiety is defined as a complicated psychological phenomenon that is unusual to language learning" [7], and a response to a condition which the external element presents a demand that threatens to exceed the student's capabilities and resources for meeting it [8]. The anxiety of speaking another language is reported to be one of the most serious problems for English as a Foreign Language (EFL) and English as a Second Language (ESL) student [9]. International students who study abroad often experience anxiety when communicating with the host in the broken target language, which means being unsure about the host people's behavior.

MacIntyre and Gardner [10] proposed a theory which provides the outline of the development of language anxiety. The model, which language anxiety might be developed, started in the beginning of learning the targeted language, when learners have difficulties in grammar and pronunciation. If the language learners are anxious and uncomfortable about making mistakes, anxiety occurs [11]. After a few repeating experiences of similar situations of language anxiety, this will influence the performance of language learning. The language learners will start to have negative thoughts and develop worries about their own performance and learning status. "Thoughts of failure, worry over how one is performing in the situation, and self-deprecating thoughts" [10] are the general arousals of anxiety.

Anxiety is the emotional equivalent of uncertainty, and individuals experience some degree of anxiety any time when communicating with the native speakers [12]. Many researchers have different perspectives on the components of language anxiety. Horwitz, et al.'s [13] theory of Foreign Language Classroom Anxiety consisted of three elements: communication apprehension, fear of negative evaluation, and test anxiety. However in 1994, it has shown that test anxiety was not a factor that contributes to language anxiety
[14]. Young [15] reported that communication apprehension, social anxiety, and low self-esteem are essential components that cause language anxiety. From the previous literature on language anxiety, there are three main factors that cause language anxiety: students' fear of negative evaluations, self-confidence, and language ego.

\section{Cultural adjustments}

As more international students begin to attend higher education systems, it is likely that they will face challenges that will have influence their emotions, which will affect them academically. Learning a foreign or second language includes learning the culture that goes along with that language [11] However, many international students still face various cultural problems, regardless of their English proficiency. In the influential study by Kwon [16], they randomly selected 165 international students and pointed out that regardless of language proficiency, all students from different ethnic groups experienced overwhelming feelings of loneliness, stress, and homesickness. A major part of homesickness results from culture shock. Even though international students are exposed to American movies and Internet material back in their home country, they still experience culture shock, which can be defined as helplessness and depression when adapting to a new cultural environment [17]. Thus, it is necessary for international students to have social interaction with local students, which will help them blend into the culture easier.

Social support is nevertheless an important factor to assist international students' adjustment to the new culture. Cheng [18] reported that international students suffer anxiety from being sick in a foreign country. The study found that international students may endure pain until it either passes or they return home for treatment, due to their frustration and feelings of inadequacy towards their lack of information or choices regarding health care. Cheng's study showed that international students worry about "being labeled and/or treated as foreign burdens and as lesser humans" (p. 85). If they were to go to a health care center, they would make choices on whether to go to their school's health care center based on their knowledge of health care in their native country or third party experiences about the school's health center. Therefore, social support is very important for international students to feel secure when they face problems, such as health issues.

\section{Learning differences and barriers}

Beyond adjusting to a new culture and language environment, international students face learning differences and barriers in the classroom. According to Kingston and Forland [19], international students can easily lose confidence in their academic ability in the new environment, even if they were academically successful in their country. There are many contributors that cause challenges and adjustments for the international students to make. Unfortunately according to Chan [20], Western educators still lack the understanding of Asian students who are likely 
to be less spontaneous and conform to their instructors. The five factors of learning differences and issues are cultural learning differences, style of obtaining knowledge, creativity, academic overload and restrictions, and advisers-students relationship.

\section{Methodology}

\section{Sample survey design}

The survey data was collected in one major university campus in Oahu, Hawaii during January and April in 2014. The goal of this project is to determine the recruited participants' level of anxiety and investigate the various reasons that contribute to experienced anxiety.

\section{Participants}

A total of 110 international students who hold either F-1 or J-1 student visas will participate in this study. They are studying at a university campus located at Oahu, Hawaii. The educational level of participants will be a mixture of doctorate and masters students. The goal on gathering the participants is to complete and investigate as many nationalities and races the university provides education to.

\section{Data collection instruments}

A questionnaire is developed on asking the participants' living experience in Hawaii and it is designed to ascertain the students' gender, age, marital status, educational background, nationality, race, financial status, length of stay in the United States, and experience in Hawaii. Students will be asked to rate their language ability in areas such as speaking, reading, listening, and writing from no knowledge at all to excellent. They will also be asked to report their social network and contact pattern in order to see whom they socialize most with. The "Types of learning difficulties and challenges faced in Hawaii" was a multiple response questions (click all that apply) including "communication ability", "course content difficulty", "limited course options", and "interactions with professors" and so on. The "Challenges faced in Hawaii" was also a multiple response questions (click all that apply) including "financial crisis", "quality of accommodation", "relationship with people" and so on.

\section{Procedures}

The participants will be recruited from one university campus located in Oahu, Hawaii. Approximately all international students, around 1000 people, will be contacted via e-mail through the help of the student housing service on campus. The e-mail will include information about the purpose of this study. Students will be asked to go to a designed website to complete the questionnaire. It is impossible to determine how many of all 1000 students will actually receive this information. However, hopefully there will be at least 100 students will be willing to participate in this research.

Data analysis

Gender, marital status, language proficiency, race/ethnicity, length of stay, social network, education background, and financial status will be investigated for their contributions to anxiety levels of international students. We used SPSS 18.0 to analyze data and adapt descriptive statistics and cross table to answer research question.

\section{Results}

\section{Data information}

There are a total of 110 participants. According to different background variables, the data information is listed below:

\section{Research question:}

What are the most common challenges of studying and living in Hawaii that are most encountered by international graduate students?

H: "Communication ability" is hypothesized to be chosen as one of the learning difficulties. As for living challenges faced in Hawaii, it is hypothesized that "financial crisis" will be the most difficult problem for international graduate students that are living in Hawaii.

Multiple choice survey analyses.

Types of learning difficulties and challenges faced in Hawaii. From the survey responses, "communication ability", "course content difficulty", "limited course options", and "interactions with professors" were chosen the most (Table 2). Cross sectional analysis of gender and learning problems was also manipulated. According the analyses, $p>.05$ shows that gender does not have a significant difference on learning problems.

Challenges faced in Hawaii. From the responses of international graduate students, most of them reported facing challenges of "financial crisis", "quality of accommodation", "relationship with people", and language (table 3). Cross-sectional analysis of gender and challenges faced while studying in Hawaii was also manipulated. Out of the eight given choices of challenges, "financial crisis" showed a significant difference between male and female respondents. The Pearson coefficient for correlation was 4.35 with a p-value of $.037(p<.05)$ (table 5). Moreover, the contingency coefficient value is .216 (table 6), gender is moderately correlated to the feeling of facing financial crisis. From the further analyses in cross-sectional analysis, more female international graduate students $(n=26)$ reported facing financial crisis than male students $(\mathrm{n}=11)$. 
Table 1. Background variables description of samples

\begin{tabular}{|c|c|c|c|c|}
\hline Background variable & Code & group & number & percent $(\%)$ \\
\hline \multirow{2}{*}{ Gender } & 1 & Male & 51 & 46.4 \\
\hline & 0 & Female ( reference group ) & 59 & 53.6 \\
\hline \multirow{3}{*}{ Marital status } & 0 & Married ( reference group ) & 18 & 16.4 \\
\hline & 1 & Single & 88 & 80.0 \\
\hline & 2 & Others : engaged, almost married, divorced & 4 & 3.6 \\
\hline \multirow{4}{*}{ What year were you born? } & 0 & Before 1969 ( reference group ) & 3 & 2.7 \\
\hline & 1 & 1970-1979 & 24 & 21.8 \\
\hline & 2 & 1980-1989 & 77 & 70 \\
\hline & 3 & After 1990 & 6 & 65.5 \\
\hline \multirow{2}{*}{$\begin{array}{l}\text { Aside from USA, have you ever studied abroad } \\
\text { for more than half a year? }\end{array}$} & 1 & Yes & 29 & 26.4 \\
\hline & 0 & No ( reference group ) & 81 & 73.6 \\
\hline \multirow{4}{*}{$\begin{array}{l}\text { What is the highest level of education you have } \\
\text { completed before coming to Hawaii? }\end{array}$} & 0 & Bachelor ( reference group ) & 38 & 34.5 \\
\hline & 1 & Master & 60 & 54.5 \\
\hline & 2 & Doctorate & 7 & 6.4 \\
\hline & 3 & Others & 5 & 4.5 \\
\hline \multirow{5}{*}{ GPA } & 1 & below 3 & 2 & 1.8 \\
\hline & 2 & $3.1-3.5$ & 21 & 19.1 \\
\hline & 3 & $3.6-4.0$ & 79 & 71.8 \\
\hline & 4 & above 4.1 & 2 & 1.8 \\
\hline & - & Missing data & 6 & 5.5 \\
\hline \multirow{5}{*}{ English ability } & - & No knowledge at all & 0 & 0 \\
\hline & 0 & Not good ( reference group ) & 7 & 6.4 \\
\hline & 1 & Average & 27 & 24.5 \\
\hline & 2 & Above average & 50 & 45.5 \\
\hline & 3 & Excellent & 26 & 23.6 \\
\hline \multirow{2}{*}{$\begin{array}{l}\text { Have you joined any foreign student } \\
\text { associations? }\end{array}$} & 1 & Yes & 40 & 36.4 \\
\hline & 0 & No ( reference group ) & 70 & 63.6 \\
\hline \multirow{5}{*}{$\begin{array}{l}\text { In general, how often do you keep in touch with } \\
\text { your family/friends at your place of residence? }\end{array}$} & 0 & Never ( reference group ) & 2 & 1.8 \\
\hline & 1 & Seldom & 9 & 8.2 \\
\hline & 2 & Sometimes & 44 & 40.0 \\
\hline & 3 & Often & 55 & 50.0 \\
\hline & - & Everyday & 0 & 0 \\
\hline \multirow{3}{*}{$\begin{array}{l}\text { Have you ever encountered any financial } \\
\text { problems while studying in Hawaii? }\end{array}$} & 1 & Yes & 49 & 44.5 \\
\hline & 0 & No ( reference group ) & 58 & 52.7 \\
\hline & - & Missing data & 3 & 3.7 \\
\hline \multirow{2}{*}{$\begin{array}{l}\text { On the whole, have you ever encountered any } \\
\text { learning problem while studving in Hawaii? }\end{array}$} & 1 & Yes & 71 & 64.5 \\
\hline & 0 & No ( reference group ) & 39 & 35.5 \\
\hline
\end{tabular}

Table 2. Frequencies of learning problem

\$Learning_problems Frequencies

\begin{tabular}{|c|c|c|c|c|}
\hline & & \multicolumn{2}{|c|}{ Responses } & \multirow[b]{2}{*}{$\begin{array}{l}\text { Percent of } \\
\text { Cases }\end{array}$} \\
\hline & & $\mathrm{N}$ & Percent & \\
\hline \multirow[t]{7}{*}{ \$Learning_problems ${ }^{a}$} & Communication_ability & 37 & $20.4 \%$ & $43.0 \%$ \\
\hline & $\begin{array}{l}\text { Interactions_with_ } \\
\text { classmates }\end{array}$ & 22 & $12.2 \%$ & $25.6 \%$ \\
\hline & $\begin{array}{l}\text { Interactions_with_ } \\
\text { professors }\end{array}$ & 27 & $14.9 \%$ & $31.4 \%$ \\
\hline & Limited_course_options & 28 & $15.5 \%$ & $32.6 \%$ \\
\hline & $\begin{array}{l}\text { Quality_of_training_not_- } \\
\text { as_good_as_expected }\end{array}$ & 19 & $10.5 \%$ & $22.1 \%$ \\
\hline & $\begin{array}{l}\text { Limited_research_ } \\
\text { resources }\end{array}$ & 19 & $10.5 \%$ & $22.1 \%$ \\
\hline & Course_content_difficulty & 29 & $16.0 \%$ & $33.7 \%$ \\
\hline Total & & 181 & $100.0 \%$ & $210.5 \%$ \\
\hline
\end{tabular}

a. Dichotomy group tabulated at value 1. 
Table 3. Frequencies of challenges while studying in Hawaii \$challenges_while_stuctying_in_Hawaii Frequencies

\begin{tabular}{|c|c|c|c|c|}
\hline & & \multicolumn{2}{|c|}{ Responses } & \multirow{2}{*}{$\begin{array}{l}\text { Percent of } \\
\text { Cases }\end{array}$} \\
\hline & & N & Percent & \\
\hline \multirow[t]{8}{*}{$\begin{array}{l}\text { \$challenges_while__ } \\
\text { studying_in_Hawaija }\end{array}$} & $\begin{array}{l}\text { Relationship_with_peopl } \\
\mathrm{e}\end{array}$ & 33 & $16.3 \%$ & $36.7 \%$ \\
\hline & Financial_crisis & 37 & $18.3 \%$ & $41.1 \%$ \\
\hline & Language & 29 & $14.4 \%$ & $32.2 \%$ \\
\hline & Quality_of_accomodation & 36 & $17.8 \%$ & $40.0 \%$ \\
\hline & Traffic & 16 & $7.9 \%$ & $17.8 \%$ \\
\hline & Lifestyle & 17 & $8.4 \%$ & $18.9 \%$ \\
\hline & Food & 20 & $9.9 \%$ & $22.2 \%$ \\
\hline & Culture & 14 & $6.9 \%$ & $15.6 \%$ \\
\hline Total & & 202 & $100.0 \%$ & $224.4 \%$ \\
\hline
\end{tabular}

a. Dichotomy group tabulated at value 1.

Table 4. Descriptive gender statistics

Count

\begin{tabular}{|ll|r|r|r|}
\hline \multirow{2}{*}{} & & \multicolumn{2}{|c|}{ Financial_crisis } & \multirow{2}{*}{ Total } \\
\cline { 3 - 4 } & & \multicolumn{1}{|c|}{00} & 1.00 & 51 \\
\hline What is your gender? & 0 & 25 & 26 & 38 \\
& 1 & 27 & 11 & 89 \\
Total & & 52 & 37 & 59 \\
\hline
\end{tabular}

Table 5. Analysis of variance for gender and financial crisis

Chi-Square Tests

\begin{tabular}{|c|c|c|c|c|c|}
\hline & Value & df & $\begin{array}{l}\text { Asymp. Sig. } \\
\text { (2-sided) }\end{array}$ & $\begin{array}{l}\text { Exact Sig. (2- } \\
\text { sided) }\end{array}$ & $\begin{array}{l}\text { Exact Sig. (1- } \\
\text { sided) }\end{array}$ \\
\hline Pearson Chi-Square & $4.352^{3}$ & 1 & .037 & & \\
\hline Continuity correction & 3.492 & 1 & .062 & & \\
\hline Likelihood Ratio & 4.431 & 1 & .035 & & \\
\hline Fisher's Exact Test & & & & .051 & .030 \\
\hline $\begin{array}{l}\text { Linear-by-Linear } \\
\text { Association }\end{array}$ & 4.303 & 1 & .038 & & \\
\hline McNemar Test & & & & $1.000^{\circ}$ & \\
\hline$N$ of Valid Cases & 89 & & & & \\
\hline
\end{tabular}

a. 0 cells $(.0 \%)$ have expected count less than 5 . The minimum expected count is 15.80 .

b. Computed only for a $2 \times 2$ table

c. Binomial distribution used.

Table 6. Symmetric measures regarding gender and financial crisis

Symmetric Measures

\begin{tabular}{|ll|r|r|r|r|}
\hline & & Value & \multicolumn{1}{c|}{$\begin{array}{c}\text { Asymp. Std. } \\
\text { Error }\end{array}$} & Approx. Tb & Approx. Sig. \\
\hline Nominal by Nominal & Phi & -.221 & & .037 \\
& Cramer's V & .221 & & .037 \\
\cline { 2 - 5 } & Contingency Coefficient & .216 & & .037 \\
\cline { 2 - 5 } & Pearson's R & -.221 & .102 & -2.115 & $.037^{\circ}$ \\
Ordinal by Ordinal & Spearman Correlation & -.221 & .102 & -2.115 & $.037^{\circ}$ \\
Measure of Agreement & Kappa & -.221 & .102 & -2.086 & .037 \\
N of Valid Cases & & 89 & & & \\
\hline
\end{tabular}

a. Not assuming the null hypothesis.

b. Using the asymptotic standard error assuming the null hypothesis.

c. Based on normal approximation. 


\section{Conclusions}

In this study, the learning difficulties for the participants, most of them reported facing problems with "communication ability", "interactions with professors", "limited course options", and "course content difficulty". As for living challenges in Hawaii, "financial crisis", "quality of accommodation", "relationship with people", and "language" were chosen the most. As a result, female international graduate students are more prone to experience financial difficulties and should be aware that it may lead to significant anxiousness. International graduate students should keep in mind that before their arrival, the challenges mentioned above are possible to experience during their stay in Hawaii. School administrators and teachers also need to pay more concern to provide assistance to avoid adjustment problems from happening.

\section{Limitations and recommendations for future research}

Due to the smaller sample size, the researcher would highly recommend to gather more samples in order to find more significant relationships from the data. Statistical tests normally require a larger sample size to ensure that it represents the general population. The timing of when the study is distributed will also greatly affect the response rate. For studies on students, it is recommended to avoid periods when students tend to be more overwhelmed with academic work. Another limitation was that all of the study measures were self-reported and were therefore susceptible to common method biases and inflation of correlations owing to spurious variables such as momentary moods or test-taking attitudes. Thus, in future study, we recommend regular follow-ups and tracking to understand the development situation of the participating cases. This may provide a better understanding of the international students' cultural emotional change and learning impact in a new environment.

\section{REFERENCES}

[1] OECD (2013), "How many students study abroad and where do they go?", in Education at a Glance 2013: Highlights, OECD Publishing. Online available from http://dx.doi.org/10.1787/eag_highlights-2013-12-en

[2] Institute of International Education. (2013). Open Doors Report on International Educational Exchange. Online available from http://www.iie.org/opendoors

[3] J. D. Kim. Stress and anxiety among Korean international students at Liberty University: Analyzed with the state-trait anxiety inventory. Liberty University Theses and Dissertations, 2009.

[4] J. D. Bremmer. (2002). The lasting effects of psychological trauma on memory and the hippocampus. Online available from

http://www.lawandpsychiatry.com/html/hippocampus.htm

[5] R. S. Feldman. Development across the life span (5th ed.).
Upper Saddle River, NJ: Prentice Hall, 2008.

[6] R. Alpert, R. Haber. Anxiety in academic achievement situations. Journal of Abnormal and Social Psychology, No. 61, 207-215, 1960.

[7] D. J. Young. Language anxiety from the foreign language specialists' perspective: Interviews with Krashen, Omaggio-Hadley, Terrell, and Rardin. Foreign Language Annals, No.25, 157-172, 1992.

[8] K. Williams. Anxiety and formal second/foreign language learning. RELC Journal: A Journal of Language Teaching and Research in Southeast Asia, Vol.22, No.2, 19-28, 1991.

[9] M. Moslehpour, C. Chou. Foreign language classroom anxiety and problem solving appraisal of EFL students taught by native and non-native English speaking teachers. The Proceedings of the Thirteenth International Symposium on English Teaching, No.2, 163-179, 2004.

[10] P. D. MacIntyre, R. C. Gardner. Anxiety and second language learning: Toward a theoretical clarification. In E. K. Horwitz, \& D. J. Young (Eds.). Language anxiety: From theory and research to classroom implications (pp. 41-54). Englewood Cliffs, NJ: Prentice-Hill, 1991.

[11] Y.W. Huang. Listening to their voices: An in-depth study of language anxiety and cultural adjustment among Taiwanese graduate students in the United States. Indiana University of Pennsylvania Theses and Dissertations, UMI 3387439, 2009.

[12] W. B. Gudykunst. An anxiety/uncertainty management (AUM) theory of strangers' intercultural adjustment. In W. B. Gudykunst (2005). (Eds.). Theorizing about intercultural communication (pp. 419-457). USA: Sage Publications, Inc, 2005.

[13] E. K. Horwitz , M. B. Horwitz, J. Cope. Foreign language classroom anxiety. The Modern Language Journal, No.70, 125-132, 1986.

[14] Y. Aida. Examination of Horwitz, Horwitz, and Cope's construct of foreign language anxiety: The case of students of Japanese. The Modern Language Journal, Vol.78, No.2, 155-168, 1984.

[15] D. J. Young. An investigation of students' perspectives on anxiety and speaking. Foreign Language Annuals, 23(6), 539-555, 1990.

[16] Y. Kwon. Factors affecting international students' transition to higher education institutions in the United States: From the perspective of Office of International Students. College Student Journal, Vol.43, No.4, 1020-1036, 2009.

[17] D. Koenigstein. Alleviating International Students' Culture Shock and Anxiety in American Academic Libraries:Welcome, Ahlan Wa Sahlan, Anyeong Hae Sae Yo,Bienvenidos, Huan ying, Sanu Da Zuwa, Shalom,Swaagat hai. Library Philosophy and Practice (e-journal). Paper 738, 2012.

[18] Y. Cheng. A measure of second language writing anxiety: Scale development and preliminary validation, Journal of Second Language Writing, No. 13, 313-335, 2004.

[19] E. Kingston, H. Forland. Bridging the gap in the expectations between international students and academic staff. Journal of Studies in International Education, Vol.12, No.2, 204-221, 2008.

[20] S. Chan. The Chinese learner-a question of style. Education and Training, Vol.41, No.6/7, 294-304, 1999. 